\title{
Bacteriolyses of Bacterial Cell Walls by Zinc (II) Ions on the Basis of the Results of Halo Antibacterial Susceptibility Tests for Metallic Salt Solutions
}

\section{Ishida T* \\ Life and Environment Science Research Division, Japan}

*Corresponding author: Dr. Sci. Tsuneo Ishida, Life and Environment Science Research Division, †336-0907 2-3-6, Saido, Midoriku, Saitama City, Saitama Prefecture, Japan, Tel/Fax: 048-881-3970; E-mail: ts-ishida@ac.auone-net.jp

\section{Research Article}

Volume 2 Issue 2

Received Date: June 29, 2017

Published Date: July 10, 2017

DOI: $10.23880 /$ oajmb-16000121

\section{Abstract}

Bacteriolyses of bacterial cell walls by zinc (II) ions on the basis of the results of halo antibacterial susceptibility tests were investigated for the nitrate and the sulfate solutions. From the results obtained by halo antibacterial tests of sulfate solutions against Staphylococcus epidermidis, the antibacterial order is $\mathrm{Zn}^{2+}>\mathrm{Cu}^{2+}>\mathrm{Ag}^{+}>\mathrm{Al}^{3+}$, in which $\mathrm{Zn}^{2+}$ ions indicate the highest antibacterial effect. Bacteriolysis of S.aureus PGN cell wall by zinc ion is due to the inhibition of PGN elongation by the activation of PGN autolysins of amidases and side-chain endopeptidase. On the other hand, bacteriolysis of E.coli cell wall by zinc ions is attributed to the destruction of outer membrane structure due to degradative enzymes of lipoproteins at $\mathrm{N}$ - and C-terminals, and also is dependent on the activities of PGN hydrolases and autolysins of amidases and carboxypeptidase-transpeptidase. Zinc ions induced ROS such as $\mathrm{O}_{2}{ }^{-}, \mathrm{H}_{2} \mathrm{O}_{2}, \cdot \mathrm{OH}, \mathrm{OH}^{-}$producing in bacterial cell wall occur oxidative stress.

Keywords: Halo antibacterial test; Zinc ions; PGN cell wall; Outer membrane lipoprotein; Biosynthesis and autolysin; Reactive oxygen species (ROS)

\section{Introduction}

Silver, copper, and zinc of transitional metals have highly antibacterial activities and are utilized as cheomotherapy agents. Recently, antibacterial activities of zinc and its complexes call attention to potential treatments such as prevention of serious diseases [1], exploitation during bacterial pathogenesis [2], and virus counter measure [3]. In this study, the halo antibacterial susceptibility tests of various nitrate and sulfate solutions against Staphylococcus epidermidis were carried out, wherein it was turned out that zinc ions had the highest antibacterial effects. On the basis of the high antibacterial activity for these zinc ions obtained from the halo antibacterial tests for metallic sulfate solutions, the processes of bacteriolyses and destructions by the antibacterial activities of zinc ion solutions were analyzed and considered against S.aureus peptidoglycon 
and E.coli outer membrane cell walls. Furthermore, the bacteriolytic mechanisms by zinc (II) ions have been revealed against both Gram-positive and Gram-negative bacteria.

\section{Method}

\section{Halo Antibacterial Susceptibility Tests}

Halo antibacterial tests have been carried out for the nitrate and sulfate aqueous solutions against Staphylococcus epidermidis in the presence of human skin surface. The other, the antibacterial reagents were prepared metallic ions $100 \mathrm{mM} / \mathrm{L}$ aqueous solutions from metallic salt reagents. The metallic salts were used manufacturing by Wako Pure Reagents and Nissan Chemistry Ltd. The preparation method is shown in Table 1 , wherein the crystalline powders of metallic salts of $0.01 \mathrm{~mol}$ are dissolved in distilled water of $100 \mathrm{cc}$, preparing metallic ion concentration of $100 \mathrm{mM} / \mathrm{L}$ as antibacterial reagents (crystalline powders of $0.005 \mathrm{~mol}$ for silver sulfate and aluminum sulfate were used).

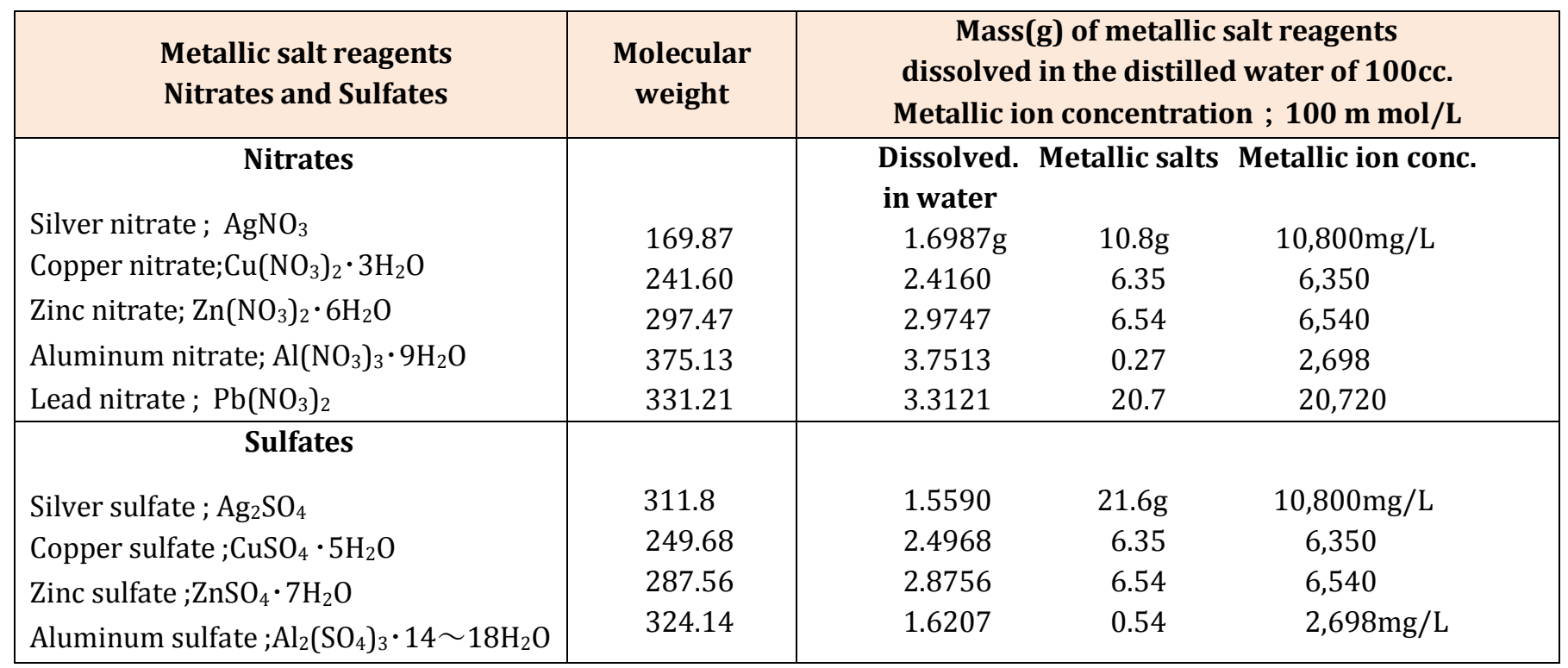

Table 1: Preparing metallic ions $100 \mathrm{mM} / \mathrm{L}$ aqueous solutions from metallic salt reagents.

Firstly, Staphylococcus epidermidis that were collected from the inside of the arms were incubated in physiological saline aqueous water solution of salt at a thermostat of constant temperature of $35^{\circ} \mathrm{C}$ through a week. Afterwards the bacteria are incubated in the standard planar agar-medium, the appearing pepite colonies are incubated in gradient medium above a week. Secondly, the incubated cells were suspended in physiological saline solution, in which they were painted and swabbed at parts of $100 \mu \mathrm{L}$ to newly prepared planar medium. Finally, the paper discs that the antimicrobial liquid was swabbed and spread were placed on the center of planar medium at $35^{\circ} \mathrm{C}$ for a week. Afterwards, measurement of the inhibition halo must be done always with ruler. Inhibitory zone width $\mathrm{W}$ is represented as $\mathrm{W}=(\mathrm{X}-8 \mathrm{~mm}) / 2$ (in $\mathrm{mm}$ ) from measured inhibitory diameter $\mathrm{X}$ and paper-disc diameter of $8 \mathrm{~mm}$, in which $\mathrm{W}$ is calculated from measured $X$.

\section{Search for Peptidoglycan (PGN) Biosyntheses and Autolysins}

The molecular structure and the action sites for PGN biosyntheses and PGN autolysins were enzymatically searched against S.aureus and E.coli.

\section{Results}

\section{Halo Antibacterial Tests}

Figure 1 indicates the bar-graphs of the relationships between various metallic ions and halo inhibitory zones width. From these values of inhibitory zone width for the nitrate solutions, it is found that the antibacterial effect has nothing for alkali metals, alkali earth metals, but, various ions of $\mathrm{Al}^{3+}, \mathrm{Zn}^{2+}, \mathrm{Pb}^{2+}, \mathrm{Cu}^{2+}, \mathrm{Ag}^{+}$indicate the antibacterial effects. The order of the antibacterial effect is as following; $\mathrm{Cu}^{2+}>\mathrm{Zn}^{2+}>\mathrm{Ag}^{+}>\mathrm{Pb}^{2+}>\mathrm{Al}^{3+}$. On the other 
hand, in sulfate solutions, $\mathrm{Al}^{3+}, \mathrm{Zn}^{2+}, \mathrm{Cu}^{2+}, \mathrm{Ag}^{+}$have higher antibacterial activities.

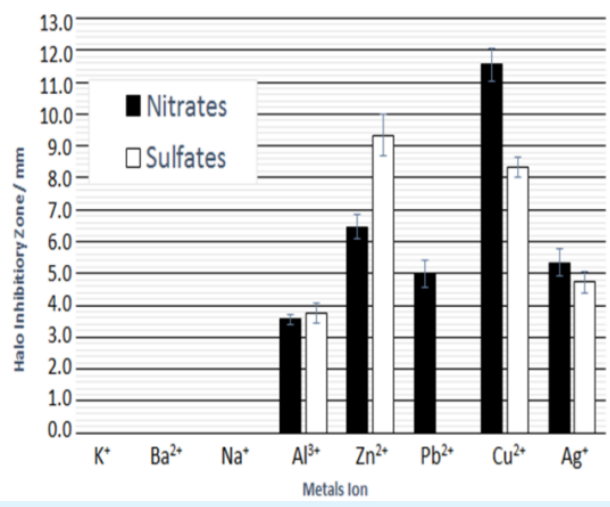

Figure 1: Relationship of various metallic ions of aluminum, zinc, lead, copper and silver nitrates and sulfates, and halo inhibitory zone (in $\mathrm{mm}$ ) by halo antibacterial susceptibility tests against Staphylococcus epidermidis.

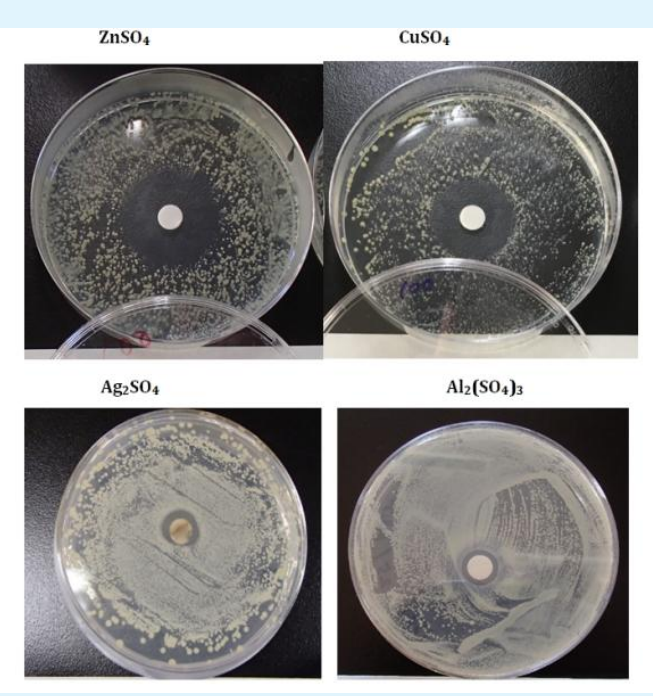

Figure 2: Sample appearance after halo antibacterial susceptibility tests in the sulfates against Staphylococcus epidermidis.
Figure 2 shows the sample surface appearances of inhibitory zone after halo antibacterial tests of sulfate solutions of $\mathrm{ZnSO}_{4}, \mathrm{CuSO}_{4}, \mathrm{Ag}_{2} \mathrm{SO}_{4}, \mathrm{Al}_{2}\left(\mathrm{SO}_{4}\right)_{3}$ against Staphylococcus epidermidis. From these observations, the antibacterial order is $\mathrm{Zn}^{2+}>\mathrm{Cu}^{2+}>\mathrm{Ag}^{+}>\mathrm{Al}^{3+}$, in which $\mathrm{Zn}^{2+}$ ions indicate the highest antibacterial effect. It is thought that this effect results from strong Lewis acid of $\mathrm{Zn}^{2+}$ ion and facility to bond with S-content cysteine.

\section{Search and Analysis}

\section{Action Sites of PGN Biosyntheses of Transglycosylase TG and Transpeptidase TP, and PGN Autolysins}

S.aureus surface cell envelop consists of teichoic acids, lipoteichoic acids, and thick PGN cell wall [4], whereas E.coli cell wall is comprised of lipid A, lipopolysaccharide (LPS), porin proteins, outer membrane of lipoprotein, and thinner 2-7 nm PGN layer in 30-70 nm periplasmic space [4]. Figure 3 shows the molecular structure of S.aureus PGN cell wall, including that indicates the action sites of PGN biosynthesis enzymes of TG/TP, and PGN forth autolysins and Lysostaphin enzyme.

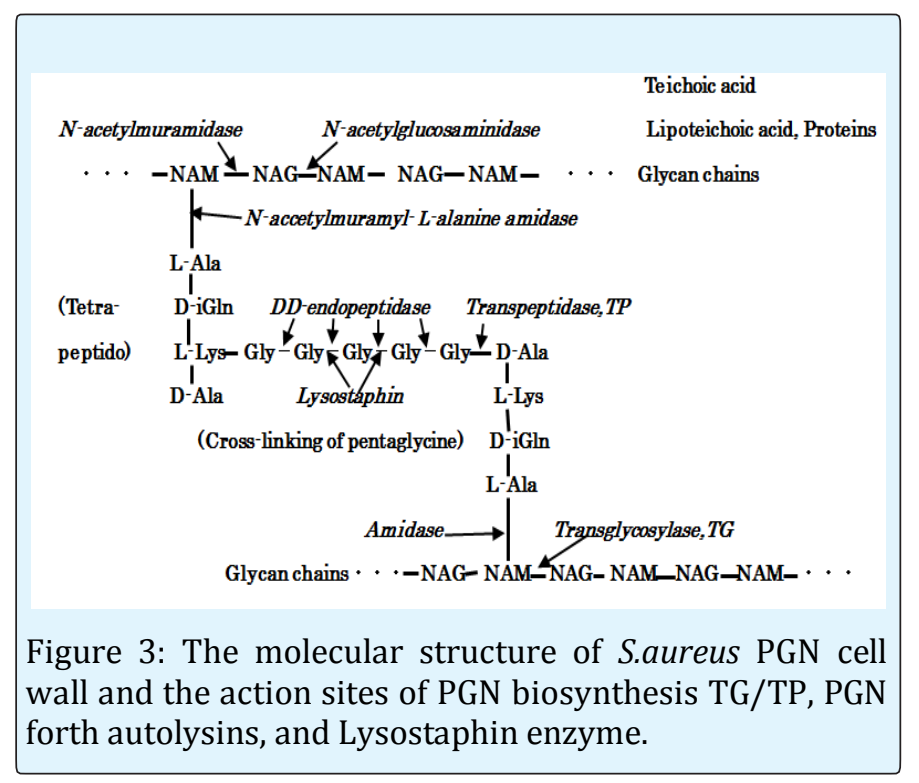




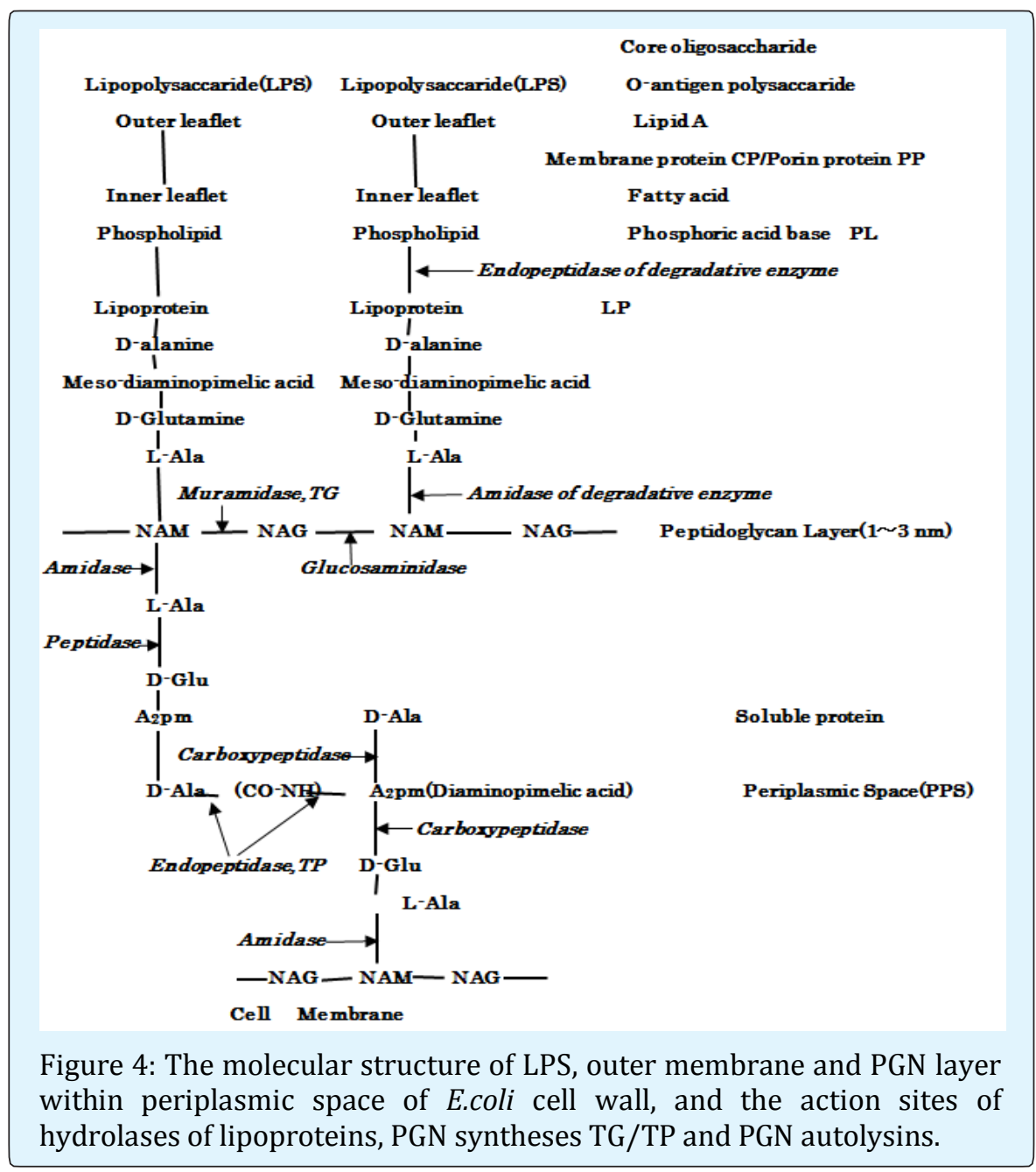

Furthermore, Figure 4 represents the molecular structure of LPS, outer membrane adjacent to PGN layer within periplasmic space in E.coli cell wall, in which indicating the action sites of the hydrolases of lipoproteins, the PGN biosynthetic enzymes of Muramidase, TG/Endopetidase, TP and the autolysins of amidase, carboxypeptidase, etc. Thus, the interactions of PGN syntheses and autolysins still influence essentially the bacteriolyses of bacterial cell walls.

\section{Discussions}

\section{Bacteriolysis of S.aureus PGN Cell Wall by Zinc Ions}

For the sake of growth of S.aureus PGN cell wall, there is necessarily required for the adequate balance between PGN syntheses and PGN autolysins. When the balance is broken, the bacteriolysis and the destruction of bacterial cell wall should become to occur. Wall teichoic acids are spatial regulators of PGN cross-linking biosynthesis TP [5], however, it is not explicit whether zinc ions could inhibit both TG and TP enzymes of PGN, whereas is due to uncertain relation between wall teichoic acids biosynthesis and PGN biosynthesis.

$\mathrm{Zn}^{2+}$ binding Rv3717 showed inactivity on polymerized $\mathrm{PGN}$ and however, it is induced to a potential role of $\mathrm{N}$ Acetylmuramyl-L-alanine Amidase [6] in PGN fragment recycling. The novel zinc-induced cell wall hydrolases are effective for PGN murein hydrolase activity and generalized autolysis; PGN hydrolase Amidase MurA [7], Lytic Amidase LytA [8], enzymatically active domain of autolysin LytM [9], zinc-dependent metalloenzyme of active amidase domain AmiE [10] as prevention of the pathogen growth, Lysostaphin-like PGN hydrolase, and glycylglycine endopeptidase LytM [11]. It is thought that the activations of these PGN autolysins could be enhanced 


\section{Open Access Journal of Microbiology \& Biotechnology}

in the inhibition of PGN elongation, in inducing simultaneously bacteriolysis and destruction of S.aureus PGN cell wall. Accordingly, it has become apparent that $\mathrm{Zn}^{2+}$ ions inhibit the PGN elongation due to the activations of the PGN autolysins.

\section{Production of Reactive Oxygen Species (ROS) against S.aureus}

For the penetration of zinc ions to PGN cell wall, the ROS production such as superoxide anion radical $\mathrm{O}_{2}{ }^{-}$, hydroxyl radical $\cdot \mathrm{OH}$, hydrogen peroxide $\mathrm{H}_{2} \mathrm{O}_{2}$ occurred from superoxide radical $\mathrm{O}_{2}{ }^{-}$molecular [12]. $\mathrm{O}_{2}{ }^{-}$and $\mathrm{H}_{2} \mathrm{O}_{2}$ permeate into membrane and cytoplasm, which DNA molecular is damaged by oxidative stress [13].

$$
\begin{gathered}
\mathrm{O}_{2}+\mathrm{e}^{-}+\mathrm{H}^{+} \rightarrow \cdot \mathrm{HO}_{2} \\
\cdot \mathrm{HO}_{2} \rightarrow \mathrm{H}^{+}+\mathrm{O}_{2} \\
\cdot \mathrm{O}_{2}{ }^{-}+2 \mathrm{H}^{+}+\mathrm{e}^{-} \rightarrow \mathrm{H}_{2} \mathrm{O}_{2} \\
\mathrm{H}_{2} \mathrm{O}_{2}+\mathrm{e}^{-} \rightarrow \mathrm{HO}^{-}+\cdot \cdot \mathrm{OH} \\
\cdot \mathrm{OH}+\mathrm{e}^{-}+\mathrm{H}^{+} \rightarrow \mathrm{H}_{2} \mathrm{O} \\
2 \mathrm{H}^{++} \cdot \mathrm{O}_{2}^{-}+\cdot \mathrm{O}_{2}^{-} \rightarrow \mathrm{H}_{2} \mathrm{O}_{2}+\mathrm{O}_{2} \\
\mathrm{H}_{2} \mathrm{O} \rightarrow \cdot \mathrm{OH}+\cdot \mathrm{H}+\mathrm{e}^{-} \rightarrow \mathrm{H}_{2} \mathrm{O}_{2}
\end{gathered}
$$

\begin{tabular}{|c|c|}
\hline $\begin{array}{l}\mathrm{Zn}^{2+}+\text { ions } \\
\text { solution }\end{array}$ & S.aureus Cell Wall \\
\hline \multirow[b]{2}{*}{$\mathbf{Z n}^{2+}$} & Teichoic acid, Lipoteichoic acid, Peptidoglycan layer, Proteins \\
\hline & $\begin{array}{l}\mathrm{Zn}^{2+} \mathbf{O}_{2}^{-}, \mathbf{H}_{2} \mathbf{O}_{2}, \cdot \mathbf{O H}, \cdot \mathbf{N O}, \mathbf{O N O O}^{-} \\
\cdot \text { Teichoic acids are spatial regulators of biosynthesis of PGN cross-linking TP enzyme } \\
\cdot \mathrm{Zn}^{2+} \text { binding proteins } \\
\cdot \text { It is unknown whether zinc ions inhibit the PGN biosynthesis TG/TP enzyme } \\
\cdot \text { Activations of PGN autolysins } \\
\cdot \text { Bacteriolysis and destruction of PGN cell wall due to inhibition of PGN elongations } \\
\cdot \text { ROS productions and the oxidative stress }\end{array}$ \\
\hline
\end{tabular}

Thus, from above-mentioned discussion, a process of bacteriolysis of S.aureus PGN cell wall by $\mathrm{Zn}^{2+}$ ions is shown in Table 2.

Table 2: Bacteriolysis and destruction of S.aureus PGN cell wall by permeability and antibacterial activities of $\mathrm{Zn}^{2+}$ ions.

\section{Bacteriolysis and Destruction of E.coli Cell Wall by Zinc Ions Permeability of Zinc Ions into E.Coli Cell Wall}

E.coli cell wall is constituted of the lipopolysaccharide (LPS), the lipoproteins (LP), and the thinner layer of PGN within the periplasmic space. The first permeability barrier of zinc ions in the E.coli cell wall is highly anionic LPS with hydrophobic lipid A, core polysaccharide, Opolysaccharide, in which zinc ions may be possible for the inhibition of LPS biosynthesis, owing to that promotes formation of metal-rich precipitates in a cell surface [14]. In zinc ion uptake across the outer membrane, the lipoproteins of $\mathrm{OmpA}, \mathrm{OmpC}, \mathrm{OmpF}$ porins have a role for at least some of these proteins in $\mathrm{Zn}^{2+}$ uptake, in which the lipoproteins have metallic cation selective and hydrophilic membrane crossing pore, to be effective for zinc transfer [15]. Zinc (II) ions react with -SH base, generating simultaneously $\mathrm{H}^{+}$. Zinc bivalent is unchangeable, forming as $-\mathrm{SZn}-\mathrm{S}-$ bond 4-coodinated.

$$
\mathrm{Zn}^{2+}+2(-\mathrm{SH}) \rightarrow-\mathrm{SZn}(\mathrm{II})-\mathrm{S}+2 \mathrm{H}^{+}
$$

Destruction of Outer Membrane Structure in E.coli cell Wall by Hydrolases of Lipoproteins at C-, N-Terminals

ZnPT (zinc pyrithione) and Tol (Tol proteins)-Pal (Protein-associated lipo-protein) complex are widely used as antimicrobial agents, however, it has recently been demonstrated to be essential for bacterial survival and pathogenesis that the outer membrane structure may be destroyed [16,17].

\section{Inhibition of PGN Elongation due to the Damage of PGN Synthesis of Zinc-Protein Amidase in Periplasmic Space, and the Activations of PGN Autolysins}

The zinc-induced decrease of protein biosynthesis led to a partial disappearance of connexin- 43 of protein synthesis in neurons [18], but it is poorly understood whether PGN biosynthesis is inhibited. Further, it is also unclear whether the both TG/TP should be inhibited by the zinc ions [19-21]. On the other hand, zinc ions were accumulated in E.coli periplasmic space, whereas the zinc 


\section{Open Access Journal of Microbiology \& Biotechnology}

ions may be spent to the activation of bacteriolysis of the cell wall. Zinc depending PGN autolysins, amidase Peptidoglycan Recognition Proteins (PGRPs) [22], zinc metalloenzymes AmiD [23], amidase zinc-containing amidase; AmpD [24], zinc-present PGLYRPs [25] serve as a substitute for the PGN autolysins. It is particularly worth noting that the enhancement of the activities of autolysins is characterized on PGN carboxypeptidase-transpeptidase IIW [26] requiring divalent cations. Accordingly, the inhibition of PGN elongation has occurred by zinc ion induced activities of PGN hydrolases and autolysins.

\section{ROS Production and Oxidative Stress against E.coli}

In E.coli, free radicals $\left(\mathrm{O}_{2}{ }^{-}, \mathrm{H}^{+}, \mathrm{OH}^{-}, \cdot \mathrm{OH}\right)$ and $\mathrm{H}_{2} \mathrm{O}_{2}$ are formed as follows[27]:

$$
\begin{gathered}
\mathrm{O}_{2}+\mathrm{e} \rightarrow \mathrm{O}_{2}{ }^{-} \\
2 \mathrm{O}_{2}{ }^{-}+2 \mathrm{H}^{+} \rightarrow \mathrm{H}_{2} \mathrm{O}_{2}+\mathrm{O}_{2} \\
\mathrm{O}_{2}{ }^{-}+\mathrm{H}_{2} \mathrm{O}_{2} \rightarrow \mathrm{OH}^{-}+\cdot \mathrm{OH}+\mathrm{O}_{2}{ }^{-}
\end{gathered}
$$

In the cell wall, reacting with polyunsaturated fatty acids:

$$
\begin{gathered}
\mathrm{LH}+\mathrm{OH} \cdot \rightarrow \mathrm{L} \cdot+\mathrm{HOH} \\
\mathrm{L} \cdot+\mathrm{O}_{2} \rightarrow \mathrm{LOO} \cdot \\
\mathrm{LH}+\mathrm{LOO} \cdot \rightarrow \mathrm{L} \cdot+\mathrm{LOOH}
\end{gathered}
$$

Zinc-containing PGRPs induce ROS production of $\mathrm{H}_{2} \mathrm{O}_{2}$, $\cdot \mathrm{O}_{2}{ }^{-}, \mathrm{HO} \cdot$, in which the ROS occur the oxidative stress

\begin{tabular}{|c|c|c|c|}
\hline $\begin{array}{l}\text { Zn } \\
\text { solution } \\
\text { soluon }\end{array}$ & \multicolumn{3}{|c|}{ E.coli cell wall } \\
\hline \multirow[b]{2}{*}{$\mathrm{Zn}^{2+}$} & $\begin{array}{l}\text { Lipopolysaccharide(LPS) } \\
\text { Lipid A, Core polysaccharide }\end{array}$ & $\begin{array}{l}\text { Outer Membrane Lipoprotein, } \\
\text { Porins Omp F,A,C }\end{array}$ & $\begin{array}{l}\text { Periplasmic Space } \\
\text { PGN layer }\end{array}$ \\
\hline & $\begin{array}{l}\mathbf{Z n}^{2+}, \mathbf{H}^{+} \\
\cdot \text { Negative charge } \\
\cdot \text { Hydrophobic Lipid A } \\
\cdot \text { Inhibition of LPS biosynthesis } \\
\cdot \mathrm{Zn}^{2+}+2(-\mathrm{SH}) \rightarrow-\mathrm{SZn}-\mathrm{S}-+2 \mathrm{H}^{+}\end{array}$ & $\begin{array}{l}\mathrm{Zn}^{2+}, \mathbf{O}_{2}^{-}, \mathbf{H}_{2} \mathbf{O}_{2} \text {, } \\
\cdot \text { Porin proteins of hydrophilic channels } \\
\cdot \text { Zn binding proteins } \\
\cdot \text { Destruction of outer membrane } \\
\text { structure due to degradative hydrolases } \\
\text { of lipoprotein at C- and N-terminals } \\
\cdot \mathrm{LOO} \cdot \mathrm{L} \cdot(\text { Fatty acid })\end{array}$ & $\begin{array}{l}\mathrm{Zn}^{2+}, \mathbf{O}_{2}^{-}, \mathbf{H}_{2} \mathbf{O}_{2}, \mathbf{O H}^{-}, \cdot \mathbf{O H} \\
\text { Zn accumulation in } \\
\text { periplasmic space } \\
\text { Inhibition of PGN elongation } \\
\text { due to activations of PGN } \\
\text { autolysins of amidase, } \\
\text { carboxypeptidase- } \\
\text { transpeptidase }\end{array}$ \\
\hline
\end{tabular}
and killing by stress damage [28].

As mentioned above, the bacteriolysis and the destruction of E.coli cell wall by the process of permeability and antibacterial activities of $\mathrm{Zn}^{2+}$ ions are summarized as in Table 3.

Table 3: Bacteriolysis and destruction of the E.coli cell wall by permeability and antibacterial activities of $\mathrm{Zn}^{2+}$ ions

\section{Conclusion}

Halo-antibacterial susceptibility tests are carried out on the nitrate and the sulfate solutions of metallic ion concentration of $100 \mathrm{mM} / \mathrm{L}$ against Staphylococcus epidermidis. In the nitrate solutions, the order of bacterial effect is as follows: $\mathrm{Cu}^{2+}>\mathrm{Zn}^{2+}>\mathrm{Ag}^{+}>\mathrm{Pb}^{2+}>\mathrm{Al}^{3+}$. The other, in the sulfate solutions, the order is $\mathrm{Zn}^{2+}>\mathrm{Cu}^{2+}>$ $\mathrm{Ag}^{+}>\mathrm{Al}^{3+}$. The appearance of the highest antibacterial activity is found to be the zinc sulfate solution. Bacteriolysis of S.aureus PGN cell wall by $\mathrm{Zn}^{2+}$ ions, whereupon the wall teichoic acids control PGN biosynthesis cross-linking TP, is due to the inhibition of PGN elongation by the activation of PGN autolysins; amidase AmiA and AmiE, PGN hydrolase Lysostaphin-like endopeptidase (Glycine cutting). On the other hand, bacteriolysis and destruction of E.coli cell wall by $\mathrm{Zn}^{2+}$ ions are due to destruction of outer membrane structure by degradation of lipoprotein at C-, N-terminals and by inhibition of PGN formation due to the activations of PGN autolysins of amidases and carboxypeptidasetranspeptidase.

In zinc ion induced S.aureus cell wall, the productions of $\mathrm{O}_{2}, \mathrm{H}^{+}, \mathrm{H}_{2} \mathrm{O}_{2}, \mathrm{ONOO}^{-}$occurs. The other, in E.coli cell wall, the productions of $\mathrm{O}_{2}{ }^{-}, \mathrm{H}^{+}$in outer membrane and $\mathrm{H}_{2} \mathrm{O}_{2}, \mathrm{OH}^{-}, \cdot \mathrm{OH}$ in periplasmic space occur. These ROS and $\mathrm{Zn}^{2+}-\mathrm{H}_{2} \mathrm{O}_{2}$ damage cell membrane proteins and DNA molecules by oxidase stress. Finally, the biomedical roles of this zinc ions having the highest antibacterial effect should be included as potential treatments for neurological diseases, brain-delivery, Parkinson's and Alzheimer's disease as well as schizophrenia, Wilson's and Pick's disease, amyotrophic lateral sclerosis, Down's 


\section{Open Access Journal of Microbiology \& Biotechnology}

syndrome, and multiple sclerosis [1]. It may become particularly important that the role of $\mathrm{Zn}^{2+}$ chelators in the brain is raised increasingly.

\section{Acknowledgements}

Halo antibacterial susceptibility tests were carried out on the Subject Research Group of Saitama Prefectural Kumagaya Girl's High School, under the leader of Teacher Reiko KOBAYASHI. The author acknowledges Ms. KOBAYASHI and Subject Research Group.

\section{References}

1. Grabrucker AM, Rowan M, Garner CC (2011) BrainDelivery of Zinc-Ions as Potential Treatment for Neurological Diseases: Mini Review. Drug Deliv Lett 1(1): 13-23.

2. Ma L, Terwilliger A, Maresso AW (2015) Iron and Zinc Exploitation during Bacterial Pathogenesis. Metallomics 7(12): 1541-1554.

3. Suara RO, Crowe JE (2004) Effect of Zinc Salts on Respiratory Syncytial Virus Replication. Antimicrob Agents Chemother 48(3):783-790.

4. Silhavy TJ, Kahne D, Walker S (2014) The Bacterial Cell Envelope. Cold Spring Harb Perspect Biol 2(5): 114.

5. Atilano ML, Pereira PM, Yates J, Reed P, Veiga H, et al. (2010) Teichoic acid are temporal and spatial regulators of peptidoglycan cross-linking in Staphylococcus aureus. Proc Natl Acad Sci USA 107(44): 18991-18996.

6. Prigozhin DM, Mavrici D, Huizar JP, Vansell HJ, Alber $T$ (2013) Structural and Biochemical Analyses of Mycobacterium tuberculosis N-Acetylmuramyl-Lalanine Amidase Rv3717 Point to a Role in peptidoglycan Fragment Recycling. J BiolChem 288(44): 31549-31555.

7. Carroll SA, Hain T, Technow U, Darji A, Pashalidis P, Joseph SW (2003) Identification and Characterization of a Peptidoglycan Hydrolase, MurA, of Listeria monocytogenes, a Muramidase Needed for Cell Separation. J Bacteriol 185(23): 6801-6808.

8. Mellroth P, Sandalova T, Kikhney A, Vilaplana F, Hesek D, et al. (2014) Structural and functional insights into peptidoglycan access for the lytic amidase LytA of Streptococcus pneumoniae. MBio 15(1): 1-10.

9. Jagielska E, Chojnacka O, Sabała I (2016) LytM Fusion with SH3b-Like Domain Expands Its Activity to Physiological Conditions. Micro Drug Resist 22(6): 461-469.

10. Zoll S, Pätzold B, Schlag M, Götz F, Kalbacher H, et al. (2010) Structural Basis of Cell Wall Cleavage by a Staphylococcal Autolysin. PloS Pathog 6(3): 1-13.

11. Ramadurai L, Lockwood KJ, Nadakavukaren MJ, Jayaswal RK (1999) Characterization of a chromosomally encoded glycyglycine endopeptidase of Staphylococcus aureus. Microbiology 145(pt 4): 801-808.

12. Morina F, Vidovic M, KukavicaB,Veljović-Jovanović S (2015) Induction of peroxidase isoforms in the roots of two Verbascum thapsus L.populations is involved in adaptive responses to excess $\mathrm{Zn}^{2}+$ and $\mathrm{Cu}^{2}+$. Botanica Serbica 39(2): 151-158.

13. Gaupp R, Ledala N, Somerville GA (2012) Staphylococal response to oxidative stress. Front Cell Infect Microbiol 2: 1-8.

14. Langley S, Beveridge TJ (1999) Effect of O-Side-ChainLPS Chemistry on Metal Binding. Appl Environ Microbiol 65(2): 489-498.

15. Blindauer CA (2015) Advances in the molecular understanding of biological zinc transport. The Royal Society of Chemistry 51: 4544-4563.

16. Dinning AJ, AL-Adham ISI, Austin P, Charlton M, Collier PJ (1998) Pyrithione biocide interactions with bacterial phospholipid headgroups. J Applied Microbiology 85(1): 132-140.

17. Godlewska R, Winniewska K, Pietrasand Z, JagusztynKrynicka EK (2009) Peptidoglycan-associated lipoprotein(Pal) of Gram-negative bacteria: function, structure, role in pathogenesis and potential application in immunoprophylaxis. FEMS Microbiol Lett 298(1): 1-11.

18. Alirezaei M, Mordelet E, Rouach N, Nairn AC, Glowinski J, et al. (2002) Zinc-induced inhibition of protein synthesis and reduction of connexin-43 expression and intercellular communication in mouse cortical astrocytes. Eur J Neurosci 16(6): 1037-1044. 


\section{Open Access Journal of Microbiology \& Biotechnology}

19. Egan AJ, Biboy J, van't Veer I, Breukink E, Vollmer W (2015) Activities and regulation of peptidoglycan synthases. Philos Trans R Soc Lond B Biol Sci $370(1679)$.

20. Singh SK, SaiSree L, Amrutha RN, Reddy M (2012) Three redundant murein endopeptidases catalyse an essential cleavage step in peptidoglycan synthesis of Escherichia coli K12. Mol Microbiol 86(5):1036-1051.

21. Ramachandran V, Chandrakala B, Kumar VP, Usha V, Solapure SM, et al. (2006) Screen for Inhibitors of the Coupled Transglycosylase-Transpeptidase of Peptidoglycan Biosynthesis in Escherichia coli. Antimicrob Agents Chemother 50(4):1425-1432.

22. Rivera I, Molina R, Lee M, Mobashery S, Hermoso J (2016) Orthologous and Paralogous AmpD Peptidoglycan Amidases from Gram-Negative Bacteria. Microb Drug Resist 22(6): 470-476.

23. Pennartz A, Généreux C, Parquet $C$, Mengin-Lecreulx D, Joris B (2009) Substrate-Induced Inactivation of the E.coli AmiD N-Acetylmuramoyl-L-Alanine Amidase Highlights a New Starategy To Inhibit This Class of Enzyme. Antimicrob Agents Chemother 53(7): 2991-2997.
24. Carrasco-Lopez C, Rojas-Altuve A, Zhang W, Hesek D, Lee M, et al. (2011) Crystal Structures of Bacterial Peptidoglycan Amidase AmpD and an Unprecedented Activation Mechanism. J Biol Chem 286(36): 3171431722.

25. Wang M, Liu LH, Wang S, Li X, Lu X, et al. (2007) Human Peptidoglycan Recognition Proteins Require Zinc to Kill Both Gram-Positive and Gram-negative Bacteria and Are Synergistic with Antibacterial Peptides. J Immunol 178(5): 3116-3125.

26. Gupta HD, Fan DP (1979) Purification and Characterization of a CarboxypeptidaseTranspeptidase of Bacillus megaterium Acting on the Tetrapeptide Moiety of the Peptidoglycan. J Biologycal Chemistry 254(13): 5672-5682.

27. Kashmiri ZN, Mankar SA (2014) Free radicals and oxidative stress in bacteria. International J Current Microbio and Appl Sciences 3: 34-40.

28. Kashyap DR, Rompca A, Gaballa A, Helmann JD, Chan J, et al. (2014) Peptidoglycan Recognition Proteins Kill Bacteria by Inducing Oxidative, Thiol, and Metal Stress. PLOS Pathogen 10: 1-17. 